\title{
RELIGIOUS EXPERIENCE AS A PERSONAL GUIDANCE BASE
}

\author{
Wahidin ${ }^{1}$, Mamat Supriatna
}

\begin{abstract}
The relationship between religion and culture will shape personally, where the interaction of both is reflected through religious experience. The purpose of this study was to analyze the students' religious experiences at Ma'had Ali IAIN Salatiga in various cultures and ethnicities. The formulation of this study problem is how students' religious experiences in Ma'had Ali IAIN Salatiga are in different cultures and ethnicities? The research method used is qualitative method, with data collection technique in the form of questionnaire and interview. To analyze the data used content analysis, while the results of the study described in narrativedescriptive
\end{abstract}

Keywords: Culture, Religious Experience, Guidannce and Counseling

JOMSIGN: Journal of Multicultural Studies in Guidance and Counseling

Website: http://ejournal.upi.edu/index.php/JOMSIGN

Permalink: http://ejournal.upi.edu/index.php/JOMSIGN/article/view/6314

How to cite (APA): Wahidin \& Supriatna, M. (2019). Religious Experience as A Personal Guidance Base. JOMSIGN: Journal of Multicultural Studies in Guidance and Counseling, 3(1), 35-50

This is an open-access article distributed under the terms of the Creative Commons Attribution 4.0 International License, which permits unrestricted use, distribution, and reproduction in any medium, provided the original work is properly cited.

\section{INTRODUCTION}

Religion is a phenomenon in human life, even a necessity that is always needed. Malinowski (Cahyono, 2011) states that there is no nation, however primitive, that has no religion and magic. Religion is not only a matter of spirit (spirit) alone, but there is a close relationship between religion as a source of values and religion as a cognitive source (Cliffort Greetz, 1998). Religion as a source of values will give birth to norms that need to be internalized in everyday life. Through this process, religious awareness will emerge (Darajat, 2010), that is, the beliefs generated by actions or practices in practicing their religion.

While religion as a cognitive source reflects the knowledge possessed by religious adherents to the beliefs they hold. In this context, understanding religion has two consequences, namely understanding is universal or individual. Universal understanding is accepted by all adherents of religion, such as religion associated with something transcendent, God, or the All-Forge Power. While

\footnotetext{
${ }^{1}$ IAIN Salatiga, Jawa Tengah, Indonesia; weaidin@gmail.com
} 
individual knowledge implies a different understanding of religious teachings by each adherent, this depends on the cognitive abilities possessed by each adherent of the religion. The existence of cognitive resources has implications for the understanding and experience of different religions.

The initial phase of forming religious experience begins through the stage of understanding the contents and teachings of religion. In this first stage, the cognitive and intellectual roles are very important. This intellectual ability is used to understand doctrines (beliefs), knowledge, to rituals in religion. Utilization of cognitive functions becomes an important part in the process of understanding religion correctly. The understanding of religion which is manifested in real behavior, will bring up the phenomenon of religious experience into its own system, which will involve a number of related elements. Each system will have an impact on religious experience.

Besides cognitive factors, religious experience is also formed through the interaction of individuals with the culture in which they live. The interaction between religious understanding and culture will determine one's religious experience. This brings the consequence that, through the same teachings but produces differences in the meaning of the religion they profess.

There are a number of factors that influence the formation of religious experience (Robert H. Thomas, 1995), namely: (1) social factors, namely the influence of education or teaching and various social pressures, (2) experiences that help religious attitudes, especially experiences of various natural factors namely, beauty, harmony, and kindness, as well as experiences of moral conflict and emotional emotional experience, (3) needs, namely factors that are wholly or partly arising from unmet needs, especially the need for security, love, price self, and threats; (4) intellectual, including various verbal thought processes.

Meanwhile, in the aspect of social factors contained elements that make up people's lives, such as: values, customs, norms, law, and culture. These elements form the identity of individuals, including religious identity (religious identity), namely the individual's process of exploring and commitment to the beliefs they hold (Griffith \& Griggs, 2001).

The process of religious and cultural dialectics in the language of anthropology is called externalization, objectivisation, and internalization (who shapes what, what funds influence who) (Malcom Walter, 1994). Externalization is a process of continual outpouring of human potential into the world through physical and mental activity or attempts at human expression of 
its definition of values that have been believed to be truth. Meanwhile the objectivity stage of human activity is to produce an objective reality, which is outside the human self or as an effort to re-definition the values that already exist in the belief in human self-awareness. The last stage of internalization in which the objective reality of human creation is absorbed by humans again.

Through these three stages, the dialectical process between religion and culture carries the consequences of religious behavior in society, thus bringing up the terms high tradition (pure religion) and low tradition (local patterned religion) (Bassam Tibi, 1991; Amin Abdullah, 2010). Expressions of religiosity as they appear in the community indicate that such a strong local tradition (low tradition) influences the original character of its formal religion (high tradition), and vice versa. For example, the results of the dialectical process in Islam gave rise to views on puritanical Islam, moderate Islam, and extreme Islam (Ridwan, 2004).

In this context, religion has implications in human life in two ways, namely: (1) as a pattern for human action (pattern for behavior) and (2) religion is a pattern of action (Malcom Walter, 1994). As a pattern for religious behavior is a guideline that directs action, while as a pattern of religious behavior is a pattern of human action. As a consequence of religion as a pattern of behavior, religion will be considered as a result of human knowledge and experience, which is not infrequently institutionalized as a mythic power. Because of this religion in the second perspective is often understood as part of the cultural system, the level of effectiveness of the teaching function is sometimes not inferior to formal religion.

Culturally, Indonesian people have high religiosity / spirituality, this can be seen from the first precept of Pancasila as the nation's guideline, namely the Godhead of the Almighty (Putra, 2011). Besides that, some Indonesian people who still believe in supernatural things, make grave pilgrimages, do penance, and so on. If you see this context indicates religious experience is very important for the life of the nation and state.

Religious experience is one of the attributes of a person's psychology. Religious experience is seen as the experience of one's psychological awareness which can be a great potential for psychological healing and personal development (Cunningham, 2011; Shorrock, 2008). Through religious experience will create spirituality that functions as part of individual awareness in an effort to respect the existence of the universe, which is associated with the 
highest power in this life (transcendent), such as God, eternity, the highest peak of truth, noble values, something meaningful, so that it often inspires feelings of empowerment, hope, humility, and awe (Eaude, 2008; Tisdell, 2003; Wright, 2000).

Richards and Bergin (2005) also stated the core characteristic of people embedded in religious experience is that they enjoy loving and sincere closeness, and harmony. Wintz \& Cooper (2001) mentions several triggers that can cause religious / spiritual experiences to emerge in one's life including; 1) Physical factors (such as illness, accident, surgery, lack of sleep or food, or childbirth experience); 2) Emotional or transition experiences (birth, making commitments such as significant relationships, marriage, or becoming a member of a community of faith, lifestyle changes, moving, stressed, or losing a job, marriage, friendship or death); 3) Near death experience (whether itself or a loved one); and 5) Spiritual Practices (meditation, prayer, rituals, or attendance at places of worship).

Religious identity is formed from a combination of religious factors (religion / belief) and culture (Berkel, Armstrong, \& Cokley, 2004). Religious identity has an important contribution to the formation of religious experience. The development of religious experience cannot be separated from culture. Culture influences our way of life, whether we think, behave and behave (Koentjaraningrat, 2009).

If examined further, religious experience can be interpreted as a feeling in religious awareness that leads to beliefs generated by actions / practice (Darajat, 2010). Understanding experience is the feelings, perceptions and sensations experienced by someone or expressed by the religious community / community, with the divine essence, namely God, as the highest reality and is transcendental in nature (Glock \& Stark, 1999). The elements of religious experience include: (1) the existence of communication with things that are divine / transcendental and (2) the context (group / community) that gives legitimacy (Subandi, 1997).

Religious experience in the current development of science (sociology \& psychology) is not focused on religious experience that is individual (personal) only, but is oriented as an experience that is oriented to the collective context, as an institutional reality (Timothy Fitzgerald, 2007; Dein, 2011). Cultural factors not only build religious experience, but also personal experience. In other words, religious experience is not separate from culture. 
Tave (1999) presents a historical picture of religious experience in AngloAmerican culture in the Middle Ages, 18th Century and Early 20th Century, by conducting studies to interpret religious experiences, so as to obtain the construct of religious experience in natural, supernatural and religious. The same thing was stated by Bender (2007) that, religious experience is a formation between culture and theology.

Religious experience is a feeling, perception and sensation experienced by a person or expressed by a religious community / community in compound communication, with divine essence, namely God, as the highest reality, with transcendental authority (Glock \& Stark, 1999).

In religious experience there is an element of feeling in religious awareness that is feeling that leads to beliefs produced by actions / practices (Darajat, 2010), which are related to something supernatural (Stark, 1999). The element of religious experience includes communication with things that are divine / transcendental and the context (group / community) that gives legitimacy (Subandi, 1997), in the context of individual and collective experience (Sharf, 2000).

Glock and Stark (1999) develop the taxonomy of religious experience by referring to the intensity of interaction with God which includes four types, namely: (1) confirming experience, people will feel what is believed to be true; (2) responsive experience, God's intervention in one's life; (3) ecstatic experience (joyful experience), intimacy in communicating with God; and (4) revelational experience, a person who not only has love for God but himself becomes a messenger of God, like someone's experience to reach the future.

While Margolif and Elifson (1979) classify religious experiences into four aspects of human life, namely physiological, social-psychological, parapsychological, and spiritual.

For the purposes of this study, indicators of religious experience that are used include: (1) submission to God, (2) loving God, and (3) trying to draw closer to God in religious awareness as a Muslim (Ghorbani, Watson, Ghranmayepour, \& Chen, 2014).

To examine religious experience in a cultural perspective, this study uses Hofstede's (2005) theory of cultural dimensions which includes: (1) power distance, (2) avoidance of uncertainty (uncertainty avoidance), individualism and collectivism (individualism versus collectivism), (4) 
masculinity and femininity (masculinity versus feminimity), and (5) time orientation.

The dimensions are intended to explore further about a cultural group that is assumed to have a shared value with "shared value", then to compare it with other groups. Cultural values can be discussed from various perspectives, for cultural values there are also other theories as proposed by Trompenaars (1993, 1997). To specialize and sharpen this study only uses the theory of Hofstede (1980) as the main reference.

Religious identity is formed from a combination of religious factors (religion / belief) and culture (Berkel, Armstrong, \& Cokley, 2004). Religious identity has an important contribution to the formation of religious awareness (religious consciousness). The essence of religious awareness is the aspect of religion that is present (felt) in the mind and can be tested through introspection, or it can also be said to be a mental aspect of religion and activities in religion (Darajat, 2010). Religious awareness can be seen based on religious dimensions. According to Ninian Smart (1969) the dimensions of religion include: (1) Rituals, (2) Mythological, (3) Doctrinal, (4) Ethical, (5) Social, and (6) Experiential. While the dimensions of religion according to Stark \& Glock (2006) include: (1) belief, (2) ritual, (3) consequential, (4) experiential, and (5) knowledge.

Based on the religious dimensions above, it can be mapped into two things, namely: (1) something related to doctrine (sacral) and (2) something related to culture. For the purposes of this research, the religious dimension which will be used as proposed by Ninian Smart consists of six aspects.

\section{METHODS}

This research methodology uses qualitative research. To photograph the dimensions of religious experience for the foundation of personal guidance. Data collection techniques used in this study were questionnaire and interview. This study wants to find out about religious experiences in different cultural diversity among students who live in Ma'had Aly IAIN Salatiga.

To reach the religious experience of students who live in Ma'had Aly comprehensively, the questionnaire is used to describe the dimensions of religious experience, where the instruments are arranged based on the theoretical constructs of the theory according to Ninian Smart (1969) and Glock 
\& Stark (2006). Through this synthesis, asphalt is gained from religious experience which includes: (1) Ritual, (2) Ethical, (3) Experiential, and (4) knowledge. In this questionnaire is not asked in depth about the influence of ethnicity / ethnicity in religious experience. Meanwhile, cultural variables which include (ethnicity / ethnicity, regional origin) are functioned as part of the respondent's identity or as a predictor.

To test the validity of the instrument made, then testing of 40 samples (students) that were not subject to research. Based on Pearson Correlation shows that after testing the validity found 5 items that are not valid because it gets $r$ count $<\mathrm{r}$ table $=0.2372$.

After validity testing is done, the next step is the reliability test. The reliability test results obtained by Alfa Crombach 0.864 on adopting spirituality and 0.787 on the religious experience questionnaire. Because Alpha Crombach's $>0.7$, the instrument can be said to be reliable and can be used in research.

This study involved 78 female respondents living in Ma'had Ali IAIN Salatiga, consisting of: 6 majors (PAI, PBA, PGMI, PIAUD, IAT, AS, and PI). The total population for this study amounted to 134 people. Data was collected using a purposive random sampling technique, namely students from different Enis who live in Ma'had Aly IAIN Salatiga precisely those who are taking semester 1 (class of 2017).

The distribution of the area of origin of students in Ma'had Aly IAIN Salatiga can be mapped into 4 groups, namely (1) Central Java and East Java (Javanese), (2) West Java (Sundanese tribe), (3) Sumatra, and (4) Kalimantan.

To deepen the study of the religious experience of students at Ma'had Aly, interview techniques are used as data diggers. The interviews were conducted on 3 students from the Javanese, Sundanese and Lampung tribes. The reason for using three respondents is that the resulting data can be richer in drawing from each tribe, namely the majority (Javanese and Sundanese) and outside tribes (Lampung).

Interview guidelines to reveal religious experiences related to ethnic / ethnic origin of students with several sections, namely (1) Student identity, which includes: name, area of origin / ethnicity, religious life of the community of origin, description of the socio-cultural conditions of the place of origin, and experience religion reflected in the dimensions of original culture, which is held up to now; (2) dimensions of religious experience, which include: (a) the most 
memorable religious experience in life (before going to Ma'had Aly and while living in ma'had), (b) the multiethnic / cultural condition of Ma'had Aly in shaping religious experience, (c) perceived religious experience (confirming type, responsive type), and (c) spiritual, religious experience that is reflected in the discovery of universal truth values), and (e) individual religious experience and experience religion that is collective.

\section{RESULTS AND DISCUSSIONS}

Based on the results of questionnaires from respondents, then the data is processed or tabulated and analyzed using SPSS ver. 17. The output from processed SPSS can be presented as follows:

The first step: analysis of linear regression equations can be seen in table 1.

Table 1.

\section{Analysis of Linear Regression Equations}

Coefficients $^{\mathrm{a}}$

\begin{tabular}{|c|c|c|c|c|}
\hline \multirow[b]{2}{*}{ Model } & \multicolumn{3}{|c|}{ Unstandardized Coefficients Standardized Coefficients } & \multirow[t]{2}{*}{ t Sig. } \\
\hline & B & Std. Error & Beta & \\
\hline 1 (Constant) & 90.301 & 9.535 & & 9.470 .000 \\
\hline Culture & 1.339 & .373 & .266 & 3.594 .000 \\
\hline
\end{tabular}

a. Dependent Variable: Religious experience

The results of the constant and the linear regression coefficient are obtained in column $\mathrm{B}$, so the regression equation: $\mathrm{Y}=90.301+1.339$. From the analysis results obtained thit $=3.5944$ and $p$-value $=0.000 / 2=0.000<0.05$ or $\mathrm{H}_{0}$ is rejected. Thus, the cultural environment has a positive effect on the religious experience of students.

The second step is to test the significance of the regression equation can be seen in table 2 below: 
Table 2

Significance Test of Regression Equation ANOVA $^{b}$

\begin{tabular}{lccccc}
\hline Model & Sum of Squares & df & Mean Square & F & Sig. \\
\hline 1 Regression & 2305.718 & 1 & 2305.718 & 12.918 & $.000^{\mathrm{a}}$ \\
\hline Residual & 30164.329 & 169 & 178.487 & \\
\hline Total & 32470.047 & 170 & & \\
\hline
\end{tabular}

a. Predictors: (Constant), Socio Cultural Academy

b. Dependent Variable: Religious awareness

The results of table 2 obtained the significance of the regression line equation from the 5 th column regression row, namely $F_{\text {hit }}(b / a)=12,918$, and p-value $0,000<0.05$ or $\mathrm{H}_{0}$ rejected. Thus, the regression of $\mathrm{Y}$ over $\mathrm{X}$ is significant or culture influences the student's religious experience.

The third step, namely the significance test of the correlation coefficient $\mathrm{X}$ and $\mathrm{Y}$. The results can be seen in table 3 below:

Table 3.

Test the Significance of Correlation Coefficients X and Y

Model Summary

\begin{tabular}{|c|c|c|c|c|c|c|c|}
\hline \multirow[b]{2}{*}{ Model } & \multirow[b]{2}{*}{$\mathrm{R}$} & \multirow[b]{2}{*}{$\begin{array}{c}\mathrm{R} \\
\text { Square }\end{array}$} & \multirow[b]{2}{*}{$\begin{array}{l}\text { Adjusted R } \\
\text { Square }\end{array}$} & \multirow[b]{2}{*}{$\begin{array}{l}\text { Std. Error of } \\
\text { the Estimate }\end{array}$} & \multicolumn{3}{|c|}{ Change Statistics } \\
\hline & & & & & $\begin{array}{l}\text { R Square } \\
\text { Change }\end{array}$ & $\begin{array}{l}\mathrm{F} \\
\text { Change df1 df2 }\end{array}$ & $\begin{array}{c}\text { Sig. F } \\
\text { Change }\end{array}$ \\
\hline 1 & $.266^{\mathrm{a}}$ & .071 & .066 & 13.360 & .071 & $12.918 \quad 1169$ & .000 \\
\hline
\end{tabular}

a. Predictors: (Constant), Culture

The results from table 3 obtained the results of the significance of the correlation coefficient from the Summary Model table. Seen in the first row the coefficient of correlation $(\mathrm{rxy})=0.266$ and Fhit $($ Fchange $)=12,918$, with $\mathrm{p}$ value $=0,000$. This means that $\mathrm{H} 0$ is rejected. Thus, the correlation coefficients $\mathrm{X}$ and $\mathrm{Y}$ are significant. While the coefficient of determination from the table above is seen in the second row, namely $\mathrm{R}$ Square $=0.66$, which implies that $66 \%$ of the variation in the variable of student religious experience can be influenced by culture. 
While based on the results of interviews with 3 respondents who came from Javanese, Sundanese and Lampung tribes, data were obtained with a conclusion that the socio-cultural environment contributed to shaping religious experience. For example, respondents (eg K) who are from Sundanese tribe, really enjoy religious life. This is because his home in the Garut area is very close to the boarding school, so since childhood he was accustomed to participating in religious activities. Until he was a teenager he always participated in religious activities in the community, such as attending majelis taklim, berzanzi, and so forth. Religious experience as a result of religious behavior that he did, inherent in him, and he called it a need.

Likewise the respondent (inisail S) who came from a tribe in Lampung, had a different experience, because his family did not pay attention to religious life well. When he chose to stay at Ma'had Aly IAIN Salatiga, he found something he had never experienced in his life. The traditions and rituals contained in Ma'had Aly mean as sacred experiences in religion.

Meanwhile, respondents (initials U) who come from Javanese, have a similar view to respondents who come from Sundanese. Although the social culture in the community is not as religious as in the ' $\mathrm{K}$ ' environment, the family pays more attention to religious life.

From data mining through interviews, there are some interesting things that need to be conveyed related to the religious experience of students from various ethnic / ethnic groups in Ma'had Aly IAIN Salatiga. First, religious rituals are inherent in student life, so that mystical and extreme experiences have not yet been encountered. Second, the religious experience of students at Ma'had Aly is relatively the same, namely feeling happiness in carrying out religious rituals. Third, the majority of their religious experience is confirming (justifying knowledge that comes from religion). Fourth, cultural differentiation exerts influence on different religious experiences.

The above research results are in line with the research of Pargament (1997) which states that one of the factors that influence religious experience is the social environment in which individuals live. In the context of environmental influences on religious diversity Yusuf (2000: 136) argues that the community environment has an important role in the development of religious experience. The role is carried out through the development of insight, habituation of worship or noble character towards students. 
Likewise in the cultural context, Jalaludin (2003: 44) asserts that religious education in educational institutions will have an influence on the formation of religious life in students. In the context of the social environment in society, a person will tend to display the behavior that is often seen, both within the family and community. If community members generally display bad behavior, immorality and even violate religious norms, then they will tend to be influenced to follow the behavior, and vice versa (Yusuf, 2000: 141).

Rossiter's research (2014) confirms that to become a person who is aware of his religion, the important thing that can be done is that the individual understands the spiritual dimension in his life and exercises to improve his spirituality. This finding implies that habituation and practice in student life in developing religious awareness are very important. Besides being equipped with religious knowledge, students need to be accustomed to living with the importance of religious awareness in their lives.

Rossiter's research results above to answer the anxiety about the decline in religious morals among students, this is as the results of the Religious Research and Training of Religion in 2000, that the decline in morals and morals of students caused, among others, due to the religious education curriculum that is too dense material, and the material prioritizing aspects of thinking rather than building awareness of a complete diversity. To form students into human beings who have faith and be devoted to God Almighty and have good morals, it is necessary to develop three integrated moral dimensions, namely moral knowing, moral feeling, and moral action (Muhaimin, 2005).

More rigorously this research is in line with the research of Thouless (2000) which states that there are four factors that influence the development of religiosity, namely: (1) Social factors, including all social influences such as; education and teaching from parents, traditions and social pressures, (2) natural factors, including morals in the form of good experiences that are natural, such as the experience of moral conflict and emotional experience, (3) the factor of the need to obtain self-esteem and needs arising from death, and (4) intellectual factors relating to verbal thought processes especially in the formation of religious beliefs.

Several existing studies reinforce that social influence including academic culture contributes greatly to the development of religious awareness. Therefore, to foster religious awareness, agrees that Ismail (2000) needs to transform from traditional religious affiliations to rational religious affiliations. 
Because traditional religious affiliations have flaws, the main thing is that not all families are able to "transference" religious teachings, values, norms and practices well. Transference is meant here is the transfer of teachings, values, norms, and religious practices from parents to children.

While rational affiliation occurs as a process or continuity of the religious model of the traditional affiliation phase. Acceptance of religion is rationally seen as a good way of religion. Thus a person will live his religious life with full awareness and without coercion. He will willingly do whatever is required of a servant to serve his Lord. Obedience and submission to God are the best way of life; the most saving and will bring happiness.

Such rationality will be achieved well if someone is equipped with adequate religious knowledge. Religious knowledge in this case will lead to an understanding of everything taught by religion. When such rationality is combined with religious emotions, it is hoped that it will give birth to what is called 'religious consciousness'.

\section{Religious Experience and Personal Guidance}

Religious experience can be realized in various aspects of human life. Religious activities do not only occur when someone performs ritual behavior (worshiping) that can be seen by the eye, but also when performing other activities that are driven by supernatural powers that cannot be seen by the eye (occurs in one's heart). Therefore, a person's diversity encompasses various sides or dimensions. According to Glock \& Stark, religion is an institutionalized system of symbols, beliefs, values and behavioral systems, all of which are centered on issues that are perceived as the most meaningful (ultimate meaning).

Signs of mental health, namely: establishment (alsakinah), tranquility (althuma'ninah), relax (al-rahah) of the mind in carrying out obligations, both to himself-society and God Almighty (Mujib \& Mudzakir, 2001). Understanding sakinah only includes calm from fear, as contained in surah al-Fath: 4, which means: "It is he who has lowered peace into the hearts of the believers so that their faith increases in addition to their (existing) faith. ". While al-thuma'ninah includes calm from knowledge, beliefs and faith. And al-rahah is a state of mind that is relaxed, calm, and without strong emotional pressure (relaxed conditions have a significant correlation with inner purity.

In this context, to conduct personal guidance based on religious experience, the individual is always directed to be able to realize the three 
aspects, namely establishment (alsakinah), calmness (al-thuma'ninah), and relax (al-rahah). In the context of Islam, these efforts can be pursued through cleansing oneself from sin (tahalli), adorning themselves with rituals (takhalli), and emptying the mind other than to Allah (tajalli).

To climb the stairs needed a guide who understands religious or spiritual life well. In terms of counseling known as spiritual guidance and counseling. Thus providing spiritual counseling training for the needs of counselors. By paying attention to religion / spirituality it can increase the ability of counselors in understanding the meaning of religion / spirituality in the lives of their clinics (Watt, 2001; Pargament, 2009).

\section{CONCLUSIONS}

Religious experience is a symbol for the continuity of religious practice, because religious experience is the direction for the implementation of religious teachings. Forming religious experience is not from a single factor, but is interrelated with one another. Uniformity of understanding methods would not guarantee the results of the same understanding due to differences in intellectual degrees, not to mention the difference in the ability of knowledge that supports in the process of understanding. As a logical consequence is the difference in the results of understanding between adherents of the same religion. As long as the understanding process fulfills the right criteria and uses relevant methods, so long as the understanding effort can be justified, although the results of understanding can differ between individuals.

\section{REFERENCES}

Ahyadi, Abdul Aziz. (1995). Psikologi Agama : Kepribadian Muslim Pancasila, Bandung: Sinar Baru Algensindo

Azra, Azyumardi. (2002). Paradigma Baru Pendidikan Nasional. Rekonstruksi dan Demokratisasi. Jakarta: Kompas

Ben-Oni Ardelean, (2012). The Ethics of the Relationship between Religious and Civil Norms, KAIROS - Evangelical Journal of Theology / Vol. VI. No. 2 (2012), pp. 163-174

Bhusan LI. (1970). Religiosity Scale. Agra: National Psychological Corporation. 
Brazdau O. (2009). The Consciousness Quotient (CQ) \& The CQ Inventory Theory and Research: New York: Ny 10003, USA, 2009

Brewczynski, J., \& MacDonald, D. A., (2006), "RESEARCH: Confirmatory Factor Analysis of the Allport and Ross Religious Orientation Scale With a Polish Sample", The International Journal for the Psychology of Religion, 16(1), 63-76

Burris, C. T., (1999), "Religious orientation scale", Measures of religiosity, 144-154.

Daradjat, Z. (1997). Peranan Agama dalam Kesehatan Mental. Jakarta: CV Haji Masagung.

Daradjat, Zakiah,. (1970). Ilmu Jiwa Agama, Jakarta: Bulan Bintang

Darajat, Zakiyah,. (1997). Membina Nilai-nilai Moral di Indonesia, Jakarta: Bulan Bintang

Dietrich, A. - Functional neuroanatomy of altered states of consciousness: the transient hypo frontality hypothesis. Consciousness and Cognition $12: 231-256,2003$

Djamari. (1988). Agama Dalam Perpektif Sosiologi. Jakarta: Proyek Pengembangan Lembaga Pendidikan Tenaga Kependidikan Dirjen Dikti.

Eslinger, M.R. - Hypnosis principles and applications: an adjunct to health care. CRNA 11(4):190-196, 2000.

Fadjar, A. Malik, Reorientasi Pendidikan Islam, Jakarta: Fajar Dunia, 1999.

Faisal, Yusuf Amir,. (1995). Reorientasi Pendidikan Islam, Jakarta: Gema Insani

Gerungan. (1988). Psikologi Sosial, Bandung: PT. Eresco

Griffiths, P. (2000). The very idea of religion. First Things, Issue Archive, May, 2000, http://www.firstthings.com/article/2007/01/the-very-idea-ofreligion-48.

Ismail SM (edt), dkk. Paradigma Pendidikan Islam, Pustaka Pelajar, Semarang, 2001

Julio Fernando Prieto Peres1, Manoel José Pereira Simão2, Antonia Gladys Nasello3, Spirituality, religiousness and psychotherapy, Peres, J.F.P. et al. / Rev. Psiq. Clín. 34, supl 1; 58-66, 2007 (master referensi) 
Koenig, H. - Handbook of religion and health: a century of research reviewed.

Langgulung, Hasan,. (2003). Manusia dan Pendidikan (Suatu Analis Psikologi, Filsafat,

Levin, J.S. - How religion influences morbidity and health: reflections on natural history, salutogenesis and host resistance. Social Science \& Medicine 43(5): 849-864, 1996.

Lukashina E. V, (2017) The religious consciousness of youth as a tool of modern marketing, European Journal of Business and Social Sciences, Vol. 5, No. 12, March 2017.

Metzner, R. - Therapeutic application of altered states of consciousness (ASC). In: Schiliclitiny, M.; Leunes, H. (eds.). Worlds of consciousness.Vol 5. VWB, Berlin, 1995.

Muhaimin, (2005). Pengembangan Kurikulum Pendidikan Agama Islam di sekolah, Madrasah, dan Perguruan Tinggi. Jakarta: PT Raja Grafindo Persada.

Nur Azizah, (2000). Perilaku Moral dan Religiusitas Siswa Berlatar Belakang Pendidikan Umum dan Agama, Jurnal Psikologi Volume 33, No. 2, 1 16, Fakultas Psikologi Universitas Gadjah Mada

Pargament, K. I., (1997). The Psychology of Religion and Coping: Theory, Research, Practice, New York: Guilford, 1997

Pecorino, P. (2000). An introduction to Philosophy. An Online Textbook. http://www.qcc.cuny.edu/socialSciences/ppecorino/INTRO_TEXT/Chap ter\%203\%20Religion/What_is_religion.htm.

Qomar, Mujamil. 2007. Pesantren (Dari Transformasi Metodologi Menuju Demokratisasi Institusi). Jakarta: Erlangga

Rakhmat, Jalauddin,. (2003). Psikologi Agama (Sebuah Pengantar), Bandung: Mizan Pustaka

Raundeley, Shaktiyanshi and Kumari, Preet, (2016). Consciousness, locus of control \& religiosity among adolescents, International Journal of Applied Research, 2(9): 517-521

Robertson, Roland (ed.). (1972). Sociology of Religion. Victoria: Penguin Books Australia Ltd. 
Rosmarin, D. H., Pargament, K. I., and H. B. Robb. (2010) "Spiritual and religious issues in behavior change," Cognitive and Behavioral Practice, vol. 17, pp. 343-347.

Rossiter, Graham, (2010). A case for a 'big picture' re-orientation of k-12 australian catholic school religious education in the light of contemporary, spirituality journal of religious education 58(3) 2010

S. E. Krauss, A. Hamzah, R. Juhari, and J. Abd Hamid. (2005). "The Muslim religiosity-personality inventory (MRPI): Towards understanding differences in Islamic religiosity among Muslim youth," Pertanika Journal of Social Sciences and Humanity, vol. 13, no. 2, pp. 173-186.

Schultz-Ross, R.A.; Gutheil, T.G. (1997). Difficulties in integrating spirituality into psychotherapy. J Psychother Pract Res 6(2):130-138.

Shaktiyanshi, R \& Kumari, P, (2016) Consciousness, locus of control \& religiosity among adolescents, International Journal of Applied Research 2016; 2(9): 517-521

Suprayogo, Imam. (2013). Pengembangan Pendidikan Karakter, . Malang:UINMaliki Press. 1993.

Thouless, R.H. (2000). Pengantar Psikologi Agama. Penerjemah: Machnun Husein. Jakarta: PT Raja Grafindo Persada.

Wesley J. Wildman and Patrick McNamara, (2010) Evaluating Reliance on Narratives in the Psychological Study of Religious Experiences, The International Journal for the Psychology of Religion, 20:223-254, 2010, DOI: 10.1080/10508619.2010.507666

Yusuf, Syamsu. (2003). Pengantar Psikologi. Bandung. PPB FIP UPI

Yusuf, Syamsu,. (2000). Psikologi Perkembangan Anak dan Remaja, Bandung: PT. Remaja Rosdakarya 